University of Louisville

ThinkIR: The University of Louisville's Institutional Repository

Electronic Theses and Dissertations

$5-2020$

\title{
A content analysis of Olivia Pope: how scandal reconfirms the negative stereotypes of black women.
}

Chelsy LeAnn Golder

University of Louisville

Follow this and additional works at: https://ir.library.louisville.edu/etd

Part of the Gender, Race, Sexuality, and Ethnicity in Communication Commons, and the Mass Communication Commons

\section{Recommended Citation}

Golder, Chelsy LeAnn, "A content analysis of Olivia Pope: how scandal reconfirms the negative stereotypes of black women." (2020). Electronic Theses and Dissertations. Paper 3471.

https://doi.org/10.18297/etd/3471

This Master's Thesis is brought to you for free and open access by ThinkIR: The University of Louisville's Institutional Repository. It has been accepted for inclusion in Electronic Theses and Dissertations by an authorized administrator of ThinkIR: The University of Louisville's Institutional Repository. This title appears here courtesy of the author, who has retained all other copyrights. For more information, please contact thinkir@louisville.edu. 


\title{
A CONTENT ANALYSIS OF OLIVIA POPE: HOW SCANDAL RECONFIRMS THE
} NEGATIVE STEREOTYPES OF BLACK WOMEN

\author{
By \\ Chelsy LeAnn Golder \\ B.A., Northern Kentucky University, 2018
}

\begin{abstract}
A Thesis
Submitted to the Faculty of the

\author{
Master of Arts
}

in Communication

Department of Communication

University of Louisville

Louisville, Kentucky
\end{abstract}

College of Arts and Sciences at the University of Louisville

in Partial Fulfilment of the Requirements for the Degree of

May 2020 



\title{
A CONTENT ANALYSIS OF OLIVIA POPE: HOW SCANDAL RECONFIRMS THE NEGATIVE STEREOTYPES OF BLACK WOMEN
}

\author{
By \\ Chelsy LeAnn Golder \\ B.A., Northern Kentucky University, 2018
}

A Thesis Approved on

$4 / 17 / 2020$

By the following Thesis Committee

Dr. Siobhan E. Smith-Jones, Chair

Dr. Mary Z. Ashlock, Co-Chair

Dr. Kaila A. Story 


\section{ABSTRACT \\ A CONTENT ANALYSIS OF OLIVIA POPE: HOW SCANDAL RECONFIRMS THE NEGATIVE STEREOTYPES OF BLACK WOMEN \\ Chelsy Golder \\ $4 / 17 / 2020$}

The purpose of this study is to answer how Scandal reconfirms the negative stereotypes of black women. Scandal's leading character, Olivia Pope, embodies the Mammy, the Jezebel, and the Sapphire. These stereotypes were invented during slavery and still used today to justify the current racial and gendered oppression of Black women.

A linkage between the stereotypes and Olivia Pope's character will be made based on an analysis of the television show. A random sampling approach was used to select a total of 14 episodes. Each of the 14 episodes were carefully examined for examples of Mammy-like, Jezebel-like, and Sapphire-like behaviors. My findings reveal that Olivia Pope is depicted as the caregiving Mammy, the hypersexual Jezebel, and the angry Sapphire.

Finally, it is essential to question how black female television characters reconfirm negative stereotypes because depicting Black women as Mammies, Jezebels, and Sapphires is one way that keeps them oppressed. 
TABLE OF CONTENTS

PAGE

ABSTRACT.

iii

HOW SCANDAL RECONFIRMS THE STEREOTYPES OF AFRICAN AMERICAN

WOMEN.

NEGATIVE STEREOTYPES OF BLACK WOMEN IN MEDIA.................... 4-7

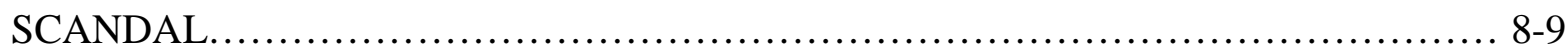

LINKAGE TO COMMUNICATION........................................... 10-10

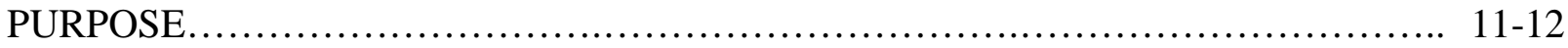

PATRICIA HILL COLLINS: BLACK FEMINISM, BLACK FEMINIST THOUGHT, AND

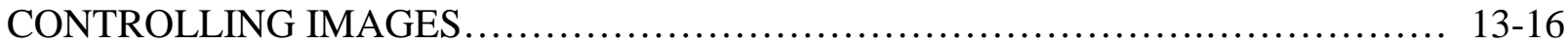

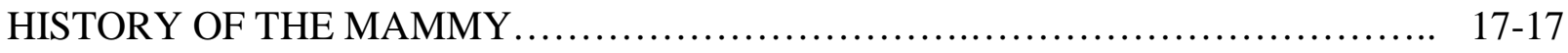

HISTORY OF THE JEZEBEL.............................................. 18-19

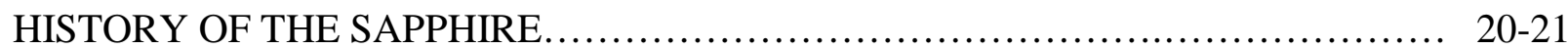

METHODOLOGY: CONTENT ANALYSIS .................................... 22-22

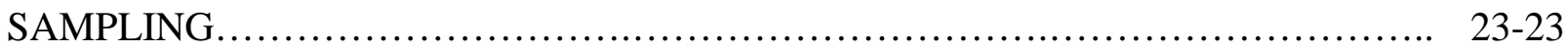

MAMMY OLIVIA .......................................................... $24-28$

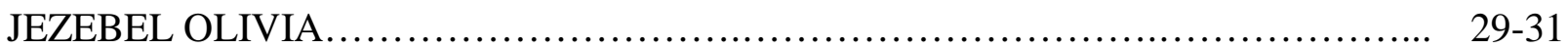

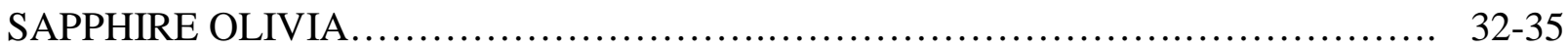

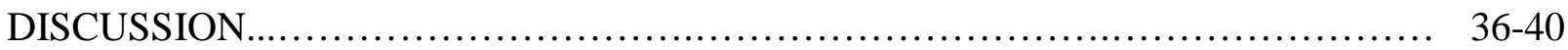

LIMITATIONS AND SUGGESTIONS FOR FUTURE RESEARCH................. 41-44

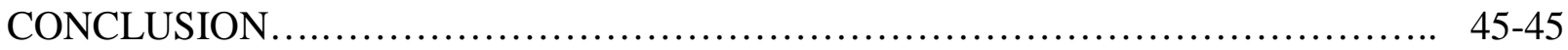


REFERENCES............................................................ 46-50

CURRICULUM VITA.................................................... $51-51$ 
HOW SCANDAL RECONFIRMS THE STEREOTYPES OF AFRICAN AMERICAN WOMEN

In most cases, African American women are not positively presented on television. The Mammy, Jezebel, and Sapphire are three historical stereotypes aimed to destroy black womanhood that appear in televised media; these stereotypes derived directly from slavery. "The racist and sexist beliefs of the slavery era systematically assaulted African American women’s self-image, and often resulted in them being subjected to sexual exploitation and victimization as a means of dehumanizing and justifying their enslavement” (Brown et al., 2013, p. 3). Unfortunately, this racist and sexist ideology concerning black women still exist in modern day, which has an effect on the expectation's society has for black women. It also effects how Black women view themselves. Thomas, Witherspoon, and Speight (2004) noted that:

African American women also have unique values and beliefs, which influence identity and functioning. For example, they have more neutral or liberal gender roles and expectations than White women (Davenport \& Yurich, 1990; Harris, 1996). They are also likely to adhere to Afrocentric values of collective survival, emotional vitality, and a being orientation to time (Brown, Lipford-Sanders, \& Shaw, 1995). (...) These values and the interaction of sexism and racism influence the identity and self-concept of African American women. (p. 427)

I believe these same identities and self-concepts are heavily revealed through black female characters in television shows, such as Scandal.

In this work, I will analyze examples of Mammy, Jezebel, and Sapphire from the television show, Scandal written by Shonda Rhimes. The series reconfirms negative stereotypes 
of black women by portraying main character Olivia Pope (Kerry Washington) as Mammy, Jezebel, and Sapphire. I argue that Olivia Pope is depicted as the black caretaker, the hypersexual black woman, and the angry black woman. Briefly, Scandal is a popular show about political corruption and power. It first appeared on the ABC network in April of 2012, and later on Netflix. Nielsen ratings show that Scandal is the highest rated scripted drama series among African Americans and watched among demographic ages 18 to 34 (Vega, 2013).

It is problematic that the series presents a black woman in such a poor manner, especially because Scandal is predominately watched by African Americans. This means there are mostly African Americans tuning into a show that does not accurately reflect black womanhood. Television can be very useful, yet detrimental to us if we are not careful. According to Heath and Petraitis (1987), “television shapes and misshapes the audience’s conceptions of the real world" (p. 97). I believe that Scandal's character, Olivia Pope is a poor representation of black womanhood because she is portrayed as a caretaking Mammy, a hoochie mama Jezebel, and a hot-tempered Sapphire. This is not how a black female character should be portrayed on television. People need to think of the message television shows such as Scandal are conveying to the black community and even non-blacks. In my opinion, it is bad enough that many people think of black women as beneath the rest of society, but it is even worse that we exploit black women further by presenting them negatively on television.

As a black, young, educated, and working female I do not enjoy shows that appear to tear down black women. I grew up in a family built on Christian principles, where we went to church each Sunday and after church my entire family met at my grandmother’s home as a tradition. My family and I ate dinner and watched television together each Sunday. We dared not to play any television show that did not have a meaningful purpose. The children in my family heard this 
saying a lot, “turn the tv off, if you can’t find anything good or educational to watch.” We also heard, “if you don’t have nothing good to say, don’t say nothing at all.” Back in my childhood days, Scandal would be considered a show that the children did not need to watch because it is not teaching anything good. Of course, my grandmother was the judge of what was deemed a good or bad television show. However, I find myself judging television shows in the same way that my grandmother used to judge television shows. I do not believe Scandal is a "good" show neither do I believe that it is conveying anything "good.” The older I get the more I understand why my grandmother cared about what we let enter our eyes and ears. My grandmother understood that television can help one figure out their place or belonging in society. She did not want us to receive negative messages that would make us feel inferior. 


\section{NEGATIVE STEREOTYPES OF BLACK WOMEN IN MEDIA}

The first historical stereotype discussed is Mammy. Mammy is a single black woman, categorized as lonely yet nurturing to others, specifically, to white families. In one study, scholar Karen Sue Warren Jewell analyzed several images of black women. Jewell (1976) noted, “Mammy has been portrayed as performing numerous functions, most of which are associated with domestic duties or responsibilities. The domestic duties which mammy has historically performed range from washing dishes to acting as a maidservant” (p. 13). Ultimately, Mammy’s life revolved around responsibilities that she was unable to neglect.

Another scholar, Betty Henry (2014), examined several images and scenes from ten contemporary films that included black female actresses. Henry’s (2014) findings stated:

Their roles are one-dimensional in that they are positioned as household servants, but the films never show them with their own families or children. Instead, their lives as a fixture in White households encapsulate their entire existence. It is as if these women do not exist beyond the borders of the White household, and by showing them only in this capacity, there is the suggestion that their labour is only noticeable in relation to the White people for whom they work. (p. 60)

Sadly, Mammy appears in television more than we would like to believe, for instance, Florida Evans in Good Times, Harriette Winslow in Family Matters, and even Nikki Parker on The Parkers. Each of these mother's act as a servant in some type of way on the television shows. Florida Evans is the superwoman that keeps the household in order. She is also known for being super sweet and polite to everyone she encounters. Harriette from Family Matters is 
similar to Ms. Evans; she is the wife that keeps the household functioning properly. Nikki Parker is very loyal to her daughter who she calls "pudding.” Nikki loves her family and will do anything to keep her family from falling apart.

Next, another depiction revealed through studying black females in media is the Jezebel representation. Jezebel is depicted as an oversexualized being. There are many of shows that portray black women as Jezebels. Eveline Versluys (2014) study finds that Olivia Pope from Scandal mirrors The Jezebel because of her sexual desires for a married man. Versluys (2014) writes, "one might expect that if she [Olivia] wanted to step away from the Jezebel stereotype, she would have aggressively distanced herself from President Grant’s behaviour” (p. 21). In the results section, I will further discuss what Versluys meant by this quote.

Next, in Black Women's Mental Health, writer Nsenga Burton discusses the representations of black female characters and their mental state. Burton (2017) discusses Being Mary Jane created by Mara Brock Akil. She describes the television series as following the traditional narrative of the black female character who encounters personal and professional life challenges (Burton, 2017). Mary Jane (Gabrielle Union) is the lead character in the show. Burton (2017) noted that, "she [Mary Jane] is beautiful, successful, hardworking, and rich, but unable to find a suitable partner or have a child, which are her two greatest desires” (p. 68). Despite her being professionally successful, she is still unhappy because she does not have a family and she feels that her desires are unattainable. Her loneliness is used to justify her desire for sex with multiple partners, portraying a modernized Jezebel.

Also discussed in Burton’s book was the television show, How to Get Away with Murder, in which actress Viola Davis stars as the lead character Annalise Keating. Burton (2017) argues: 
The character of Annalise represents a hybrid of stereotypical physical and behavioral characteristics of the Sapphire [as discussed in the next section] and Jezebel characters, engaging in sexual relationships outside of her marriage and inappropriate sexually tense behavior with her students. Annalise will swiftly "sass" or put people in their place, particularly when they have attempted to cross her. (p. 65)

Often enough these characters are portrayed as multiple stereotypes. Annalise is viewed as the harlot, but she is also viewed as hostile. When black female characters possess hostile characteristic traits, the world considers them to have Sapphire-like behaviors, which leads me to my next point.

The final well-known representation of black women is the Sapphire, also known as “[T]he Angry Black Woman” (Grayman, 2005, p. 3). Sadly, her reason for being angry is not considered excusable:

The term Sapphire originated from the show Amos ' $n$ ' Andy. According to Callen (2012): This filmic characterization of Black womanhood was first introduced to the American public as Sapphire Stevens by way of the radio turned television show, Amos ' $n$ ' Andy. On the show, Sapphire was the aggressive, emasculating, and nagging wife of character, George 'Kingfish’ Stevens, who was known for being a lazy, unemployed con artist. Since the role of Mrs. Stevens was introduced to the mainstream public, Sapphire has often been used to characterize a Black woman who voices dissent over the least infraction. (p. 14)

In the Oppositional Gaze: Black Female Spectators, hooks (1992a) writes a poem about her initial experience watching Amos ' $n$ ' Andy for the first time as a child. hooks (1992a) writes: 
She [Sapphire] was there to soften images of black men, to make them seem vulnerable, easygoing, funny, and unthreatening to a white audience. She was there as man in drag, as [a] castrating bitch, as someone to be lied to, someone to be tricked, someone the white and black audience could hate. (p. 97)

Forcing the Sapphire stereotype on black women only makes it much more difficult for society to respect black women. Along with the Sapphire, the Mammy, and the Jezebel are three of the most controlling and detrimental images of black women that attack both their race and gender. 


\section{SCANDAL}

Unfortunately, each of the stereotypes are present in the political thriller series, Scandal. Olivia Pope is an African American woman, appearing to be in her early or mid-30's. Pope is a former lawyer who serves as a crisis manager at her management firm, Olivia Pope \& Associates in Washington, D.C. She is also former communications director for the White House.

Fans know Olivia Pope for having a notorious warrior attitude and her close relationship with the White House staff and with president, Fitzgerald "Fitz” Grant (Tony Goldwyn). To Olivia herself, she is a strong, independent and powerful woman who just so happens to be in love with the most powerful man, President Grant. She never once thinks that being in love with the most powerful white man could overshadow her own power. The show seems to imply that Olivia acts as a personal maid or servant of Mr. Grant. Although, it is her job to assist Mr. Grant, there are parts in the show where Olivia goes over and beyond for him. Not only does Olivia go the extra mile for Mr. Grant by cleaning up his mistakes and assisting him on and off the clock, she finds herself sleeping with him. Olivia and Mr. Grant's relationship is rocky throughout the entire show. One minute they are business partners, then lovers, and next they are boxing opponents.

Mr. Grant is not the only character in the show with whom Olivia interacts on a frequent basis. Olivia is notorious for her savage-like attitude towards her coworkers, clients, and her father. For instance, Olivia's relationships with her coworkers such as Jake Ballard (Scott Foley), Quinn Perkins (Katie Lowes), and Cyrus Beene (Jeff Perry) are very rocky. Her relationship with her father Rowan “Eli” Pope (Joe Morton) is even rockier. Olivia’s relationships with them are 
important because through her interactions with them, viewers are able to see her negative Mammy-like, Jezebel-like, and Sapphire-like attributes. 


\section{LINKAGE TO CCOMMUNICATION}

As a black female with childhood aspirations to become an actress, I am displeased that black women are undoubtingly degraded on television. I remember years ago when I first found myself drifting away from television shows—especially those that did not uplift black women. It was not until 2017, a close friend convinced me to watch the hit series, Scandal. My friend said that she was pleased to see a black female character that seemed to go against the old stereotypes. For once, viewers did not see a black female character who was poor and trying to make it out of the ghetto by sleeping with rich men. Indeed, this was true. Olivia Pope is a successful black woman; she never even experienced the ghetto. However, after watching the show repeatedly, I became curious about the negative portrayals of African American women that are presented in the show.

Repeatedly throughout the history of television, black women are devalued, adding to the difficulty of black women finding their purpose. Gordon (2008) writes:

These concerns are likely to be especially relevant for African American girls, who face the challenges of solidifying positive racial and gender identities within a more global personal identity (Phinney, 1990). As they work to discover themselves and their value in society, these girls are simultaneously bombarded with negative media images of their racial and gender groups. (p. 245)

Therefore, it is essential that we study the portrayals of black women in television because television shapes our world. That said, we must be mindful of what we see and take in as truth when watching television. 


\section{PURPOSE}

The purpose of this study is to explore Scandal for occurrences of the three negative tropes of black women that are prevalent in the television show, specifically The Mammy, The Jezebel, and The Sapphire. Some of Scandal's black feminist viewers state Olivia Pope is misrepresenting blackness and black womanhood; others say she is too complicated to understand. Gomez and McFarlane’s research discusses their critiques concerning how Olivia represents blackness. According to Gomez and McFarlane (2017):

The complex and contradictory ways in which Olivia is represented on Scandal, make it hard to know where to place her, or which box to check off. Is Pope an impressively complicated black female character ... Or is she an example of integration-meanscapitulation to the white power structure? (p. 4)

Despite the many different arguments, I am here to explain my viewpoint. In this work, I analyze episodes from the television show Scandal, to answer the following research question:

How does the television show Scandal reconfirm negative stereotypes of black women? To explore this question, I provide a literature review followed by the theory section. Third, my methodology section outlines the conceptual framework in which this study was built, including sampling and data collection procedures. Fourth, in the results section, I discuss the major themes of these findings. Lastly, in the conclusion section, I reflect on the limitations of this study and emphasize the importance of future studies concerning Mammy-like, Jezebel-like, and Sapphire-like black female characters in television. 
In the next section, I provide a literature review regarding issues of black women depicted as Mammies, Jezebels, and Sapphires, as discussed through Patricia Hill Collins’ (1990) book Black Feminist Thought and later revised book in 2000. 


\section{PATRICIA HILL COLLINS: BLACK FEMINISM, BLACK FEMINIST THOUGHT, AND CONTROLLING IMAGES}

To better understand these negative stereotypes introduced through Scandal's leading character Olivia Pope, one must understand Black Feminism and Black Feminist Thought. In a world where everyone desires to define himself or herself, we find that Black Feminist women are no different. Inspired by the racial solidarity of the Black Power movement, radical black women, later called Black Feminists, came together in the late 1960s and early 1970s to fight against racism and sexism (Breines, 2007). Black Feminists have been fighting for equality for quite some time and experienced much backlash during the process. Breines (2007) notes that "they often found White women [White feminists] ignorant of race and class and insulting in their analyses and outreach” (p. 21). For this reason, Black Feminists stuck together and did not join White Feminists in The Feminist Movement. A black scholar, Patricia Hill Collins (2000), states:

Black feminism remains important because U.S Black women constitute an oppressed group (...) as long as Black women’s subordination within intersecting oppressions of race, class, gender, sexuality, and nation persists, Black Feminism as an activist response to that oppression will remain needed. (p. 22)

Black Feminism opened up doorways for Black female scholars to discuss and rationalize the problems they were facing as black females in America. Black Feminist Thought was created in support of Black Feminists. Black Feminist Thought consists of collective ideologies and ideas produced by black women. According to Collins (2000): 
The overarching purpose of U.S. Black feminist thought is also to resist oppression, both its practices and the idea that justify it. If intersecting oppressions did not exist, Black feminist thought, and similar oppositional knowledges would be unnecessary. As a critical social theory, Black feminist thought aims to empower African-American women within the context of social injustice sustained by intersecting oppressions. Since Black women cannot be fully empowered unless intersecting oppressions themselves are eliminated, Black feminist thought supports broad principles of social justice that transcend U.S. Black women’s particular needs. (p. 22)

In Black Feminist Thought, Collins explains the objectification of black Women as the other. "Maintaining images of U.S. Black women as the other provides ideological justification for race, gender, and class oppression” (Collins, 2000, p. 70). The Mammy, the Black Matriarch, and the Jezebel are all controlling images directly relating to black women's sexuality, which is used to keep them oppressed. It is important to point out that black women's sexuality is intertwined with each of the images, because so much of what we think is pure and not pure, seems to be shaped by sexuality. So, consequently, the images had to convey some type of message about black women's sexuality to keep them from rising above oppression. According to Collins (2000), "these prevailing images of Black womanhood represent elite White Male interests in defining Black women's sexuality and fertility (...) they help justify the social practices that characterize the matrix of domination in the United States” (p. 84).

According to Collins (2000), Mammy is depicted as asexual; therefore, she has time to tend to children that are not her own. Like the "good" white mother, Mammy is supposed to deny her female sexuality. Because Mammy denies her female sexuality and chooses to act as a caretaker for white families, she is considered the "good" black mother (p. 74). She is defined by 
what she can do for whites and what she is able to give up in her own personal life. It seems that the idea of "good" is to basically deny yourself and conform to femininity. Because Mammy is a caretaker for whites, she cannot have other obligations, she cannot satisfy herself—or find satisfaction in sexual pleasure; she must be completely dedicated to her servant duties. This is what makes Mammy "good” in the eyes of whites.

In contrast, the Black Matriarch mother represented mostly a sexual being and a "bad" black mother. She is opposite of the Mammy image. She does not take care of white families, instead she is a single parent that takes care of her own family and she has an extremely rude demeanor. She is often seen as too assertive or strong. “One source of the matriarch's failure is her inability to model appropriate gender behavior. Thus, labeling Black women unfeminine and too strong works to undercut U.S Black women’s assertiveness” (Collins, 2000, p. 76-77). Again, the whole idea of appropriateness and what it means to be a "good" woman is the idea of being pure and denying yourself. Putting the Black Matriarch title on black women implies that they were doing something wrong. It is important to note that the Black Matriarch and Sapphire are very similar. Donovan (2011) noted that "Sapphire shares many Matriarch traits, and, because of this commonality, the two images are difficult to disentangle” (p. 460). Similar to the Black Matriarch, the Sapphire is aggressive with a bad attitude that cannot be tamed.

Lastly, the Jezebel is discussed as a controlling image. The Jezebel is the most sexual image out of all of the controlling images. “Because efforts to control Black women’s sexuality lie at the heart of Black women's oppression, historical Jezebels and contemporary "hoochies" represent a deviant Black female sexuality” (Collins, 2000, p. 81). The Jezebel is depicted as a wild "hoochie mama" with inappropriate sexual desires. Consequently, Jezebel becomes masculinized because her sexual appetite resembles a man's sexual appetite. Portraying black 
women as the Jezebel image provided the excuse to title black women with strong sexual desires as bad.

Next, I will discuss the history behind each of the controlling images discussed above. 


\section{HISTORY OF THE MAMMY}

Patricia Hill Collins (2000) noted Mammy as the first controlling image used to oppress black women in America, stating that “[M]ammy symbolizes the dominant group’s perceptions of the ideal Black female relationship to elite White male power” (p. 72). She was the ideal black female because she was very loyal and accepted her subordination to white power. Mammy is one of the most influential negative depictions of the black woman, in which derived from slavery. It is stated that:

The concept of the Mammy as a house servant was introduced in the 1830 s as a stout, dark-skinned, smiling, hardworking, doting woman who offered the only "redeeming embodiment of Black womanhood imaginable within the intertwined race, class, and gender distinctions of the Old South.” (Turner, 2002, as cited in Henry, 2014, p. 58) Mammy quickly became a part of southern culture. Mammy represented the African American women forced to work in the slave owners' house. The Mammy is a faithful, obedient, domestic servant who loves, nurtures, and cares for the White master's children better than she does her own (Chaney \& Robertson, 2016, p. 133). Her time belongs to her master’s family. According to Bogle (2001), "the servants were always around when the boss needed them. They were always ready to lend a helping hand when times were tough” (p. 36). Often, Mammy is depicted as being so concerned with taking care of others that she neglects to take care of herself. Although, U.S black females are no longer enslaved, there is still a narrative being broadcast on television that portray black female characters as if they were still enslaved Mammies. 


\section{HISTORY OF THE JEZEBEL}

Like the Mammy, the Jezebel is another illustration of the black woman. It is important to discuss that Jezebel is broken up into two types. There is the racial "black” Jezebel and the Biblical Jezebel; both are very similar to one another. First, I will discuss the raced "black" Jezebel.

Scholars like Eveline Versluys discuss the linkage between the black Jezebel and its arising from slavery. She writes (2014), “Just like the stereotype of the Mammy, the Jezebel was invented to rationalize the concept of slavery” (p. 11). Historically, during slavery, whites, including white women, believed that black women were immoral. White women were seen as pure while black women were seen as sluts. White men used this stereotype to their advantage. According to Pilgrim (2002):

The Jezebel stereotype was used during slavery as a rationalization for sexual relations between white men and black women, especially sexual unions involving slavers and slaves. The Jezebel was depicted as a black woman with an insatiable appetite for sex. She was not satisfied with black men. The slavery-era Jezebel, it was claimed, desired sexual relations with white men; therefore, white men did not have to rape black women. (2002, para. 6)

White men would sexually abuse black women because of the belief that black women were licentious and enticing the white slave-owners with their nudity or skimpy clothing, although the clothes they wore were provided by the slave-owners. If black women are seen as 
sexual predators craving sex from white men, then that would justify why it was "ok" for white men to rape black women during slavery days.

Due to this belief, rape and sexual violence against them was not a crime. Versluys (2014) noted that:

This image of the virtuous Victorian lady [white lady] contrasted sharply with African American women working in slavery. Many black women were forced to work half naked; laboring [sic] in cotton fields with their skirts hiked up. In order for white slaveowners to reconcile with the fact they forced these women to nudity, the Jezebel [sic] image was created to justify their cruel behavior [sic] and reaffirm white superiority. (p. 11)

Moving on to the Biblical Jezebel, like the raced Jezebel, in the Bible, Jezebel is a sexual, dangerous, and enticing woman. Scriptures warn God's people to stay away from the strange woman, because of her man-eating, promiscuous, and deceitful spirit.

In Tamura Lomax’s book, Jezebel Unhinged: Losing the Black Female Body in Religion \& Culture, she discusses the Biblical Jezebel. Lomax (2018) writes that the biblical Jezebel is wicked, immoral, and seductive. She also believes there is a close relationship between the Biblical Jezebel and the raced Jezebel. She argues both exist to monitor or control female blackness and or femininity. She also believes that the Jezebel in the Bible is used to justify the perverted hearts and eyes of the men in the church. 


\section{HISTORY OF THE SAPPHIRE}

Lastly, the Sapphire is another illustration of the black woman. The Sapphire represents an angry black woman, who often talks back to authority and is very assertive. In hooks’ (1989) book, Talking Back: Thinking Feminist, Thinking Black, she states, “talking back is speaking as an equal to an authority figure” (p. 5). During encounters with black women White people have often attempted to silence and shift the blame to them. Jones and Norwood (2016) write:

These encounters all carry the risk that if a Black woman were to challenge embedded assumptions, the focus would shift from the aggressor's act to the appropriateness of the Black woman's response. Indeed, responding to any of the affronts summarized in this part [sic] risks the all too familiar conclusion: there she goes—-that Angry Black Woman! Why is she so angry? So bent out of shape? So sen-si-tive? In an instant, a Black woman who pushes back against her marginalization gets transformed by society into the "Angry Black Woman.” Loud. Erratic. Uncontrollable. Full of attitude. The problem becomes the Black woman as opposed to the conditions to which she is responding. (p. 2044)

Nevertheless, I believe if black women were not seen as less than by white controlling men, there would be no need for them to "talk back," "speak out," or "stand up" for themselves. Therefore, this ideology must imply that black women are beneath someone or under the strict instructions of someone or some group. This is evidence that black women are not equal in our society.

The Sapphire is extremely assertive. Assertiveness is distasteful and violates American society’s expectations, especially when underrepresented minorities express it (Grier \& Cobbs, 
1968). "Due to personal reasons and a plethora of social injustices, black women have many reasons to be angry” (West et. al., 2016, p. 393). However, society does not see these as legitimate reasons. Therefore, the perception remains that black women are unnecessarily assertive and aggressive. Garrison and Jenkins’s (1986) study found racial differences in people’s perceptions of assertiveness:

Blacks and whites view assertiveness differently (...) there needs to be more attention on the issue that black's, and white's definition of assertiveness is different (...) Based on culture differences, what whites think is assertive, blacks may not view as assertive. (p. 165)

In addition, Patricia Hill Collins suggests that black women who practice assertiveness are threatening to white patriarchal definitions of femininity. "To ridicule assertive women by labeling them Sapphires reflects an effort to put all women in their place” (Collins, 1986, p. 17). Again, naming black women Sapphires is a "politically correct” way to shame black women for speaking up, as if they did something wrong.

In summary, because these negative stereotypes already exist, there are not easy ways for black women to get around them. If black women show any signs of Mammy, Jezebel, or Sapphire there is a chance that others may categorize them as such. 


\section{METHODOLOGY: CONTENT ANALYSIS}

The conceptual framework on which I build this study recognizes the negative portrayal of black women in television. The purpose of this study is to answer how Scandal reconfirms negative stereotypes of black women. As stated before, I am a black woman with a unique lens. I do think that black women should exercise their freedom, however, I disagree with black women acting in a way that reconfirms these historically negative stereotypes. Undoubtedly, Black female characters depicting Mammies, Jezebels, and Sapphires could not blatantly be put back on television, therefore, these stereotypes are deeply hidden. However, as I watched the show

Scandal over and over, I started to discover these negative tropes still exist and they exist within Olivia Pope’s character. Below, I describe my process for examining the television show for examples of the stereotypes. 


\section{SAMPLING}

In this section, I will discuss details about Scandal and my experience with watching the television show. First, Scandal ended with a total of 124 episodes and seven seasons. There is season one with seven episodes, season two with 22 episodes, season three with 18 episodes, season four with 22 episodes, season five with 21 episodes, season six with 16 episodes, and season seven with 18 episodes. I selected two episodes from each of the seven seasons, analyzing 14 episodes. To get those 14 episodes I used random sampling: I placed the name of each episode on a piece of paper in one of the seven appropriate cups, representing each of the seven seasons of Scandal. I drew from the cup with season one episodes first. Lastly, I drew from the cup with episodes from season seven. Episodes five and six were selected from season one; episodes nine and 22 were selected from season two; episodes five and one were selected from season three; episodes 19 and 10 were selected from season four, episodes 15 and 11 were selected from season five; episodes one and 16 were selected from season six; episodes 14 and 16 were selected from season seven.

I carefully viewed and analyzed the episodes, watching each from beginning to end at a minimum of three times. When I found examples of the stereotypes, I paused the episodes to make a note of the example along with the time the example occurred. I watched all episodes until I reached theoretical saturation. 


\section{MAMMY OLIVIA}

Olivia Pope is portrayed as a motherly figure to the people closest to her; she is depicted as very nurturing. She often gives a helping hand and meaningful advice to others, neglecting her own well-being. In Patricia Hill Collins’ (2000) book, Mammy is one of the first stereotypes discussed. Collins discusses how the Mammy depiction is a controlling image of black women and portrays them as the helpers that cannot help themselves. In my opinion, Olivia Pope does tend to accept her caretaking attributes. She never even expresses among herself or with any other character her concerns about assisting others so much that she has to neglect her own personal life at times.

In season one, episode five of Scandal, Olivia Pope is presented with an issue where she is expected to comfort the father of a missing white female. Olivia rushes into her office building, Olivia Pope \& Associates, where she discovers her employee and a customer waiting for her arrival. Olivia’s employee, Quinn Perkins (Katie Lowes) lets Olivia know that the father of the missing girl would like to speak with her:

Olivia: “Quinn! Who is this?”

Customer: "Hank Tanner. I am Amanda’s father; it is a pleasure to meet you.”

Quinn: “I stopped by Amanda’s place and found Mr. Tanner outside.”

Customer: "Amanda said that she came and worked for you after she left the White House.”

Olivia: "Yes, that's right." 
Customer: “I don’t mean to be a bother here, but I’ve been talking to Mandy every day since she's been in the hospital, so I decided to come up here and make sure everything is all right. Her mother is really worried about her.”

Quinn: “It’s ok Mr. Tanner everything is going to be fine. I promise!”

Olivia: “Mr. Tanner you look like you could use a cup of tea. Quinn would you help me get some tea for Mr. Tanner?”

(Olivia and Quinn walk away)

Olivia: "What you did back there, you made a promise. We don't make promises.” Quinn: "But-”

Olivia: "Amanda Tanner is dead!"

Quinn: "What she’s dead? How do you know?”

Olivia: “We know but we can’t tell him we know because we are not supposed to know when there is no body. So, right now we are going to go back in there and give that nice man a cup of tea and tell him we are doing our best to find his daughter, and don’t ever promise an outcome we can’t deliver.” (Rhimes, 2012).

Quinn has a surprised look on her face. Olivia walks away and makes a phone call to Fitz. She yells at Fitz because she is under the impression that he murdered Amanda Turner. Olivia is upset because she lied to Amanda Turner's father in order to protect Fitz. Here we see Olivia's caretaker qualities; her goal is to do everything in her power to protect Fitz and Amanda Tanner's father. Olivia seeks to ignore her personal duties and in order to cater to them. Olivia is very nurturing, especially when it comes to protecting Fitz; she will do anything for him.

Similarly, to the example above, Olivia is portrayed as the Mammy again when she feels a burden to now help a missing black girl named Alisha Francis. I am not quite sure that the 
color of the girl's skin actually means anything, being that Olivia reacts the same way when the white girl, Amanda Turner went missing. In episode 14 of season seven, Olivia has an encounter with the father of a missing black girl. Apparently, the black girl admires Olivia, so the father wanted Olivia to help find his daughter. Expectations are for Olivia to fulfill this request. Olivia takes on the case and treats the case as if she was looking for her own daughter. I believe this reveals the nurturing side of Olivia. Olivia uses her connections with President Grant to help solve the crime. She finds out that Alisha was on a secret government list that included the names of females that government officials have attempted to have sex with. Olivia presents this information to President Grant. Olivia knew that the information could backfire on her; she knew it would be tough going up against government officials. However, the Mammy in Olivia will not let her neglect her obligations to Alisha’s father. Later, we find out that Alisha committed suicide because she was not hired as an intern for the White House because she refused to have sex with one of the government officials. After, Alisha's father hears this news, he is very hostile towards Olivia. He is outraged with Olivia and blames her for his daughter's death, stating that his daughter admired Olivia and wanted to be like her and work at the White House. I found myself upset with Olivia because she went out of her way once again to help someone before helping herself. I was even more mad because the father was disrespectful to Olivia when he did not get the results he wanted. It reminds me of slavery days; the caretaker was only respected or celebrated when she did something "useful" such as, washing dishes or fixed dinner for slaveowners and their families. If she failed at her duties she was physically or verbally abused. I can only imagine what happened when a slaveowner broke a dish or accidentally undercooked a meal. 
In season one, during episode six, there is a flashback of a conversation between Olivia and Fitz. Olivia finds herself in a heated discussion, due to Fitz firing her as a staff member on his presidential campaign. Olivia is very hurt and feels the need to let him know that she deserves another chance at being in his campaign. Olivia states to Fitz, "I am good, I am brilliant, I will eat, breathe, and live Fitz Gerald Grant every minute of every day, you'd be lucky to have me.” Olivia is clearly promoting her caretaker skills. She wants Fitz to know that she will take great measure in order to take care of him. Despite, his initial action to fire her, she is still willing to do whatever is necessary to please Fitz. I am outraged because Olivia is depicted as a black woman desiring to please a white man who clearly does not know her worth. Fitz fired Olivia and I do not like that she begs for her job back. This reminds me of a Mammy, desiring to protect at all cost.

Lastly, in season two, episode 9, Olivia and Cyrus talk about relationships over a glass of wine. It is very apparent that Olivia is single and cannot keep her love life together. As Olivia and Cyrus discuss relationship problems at what seems like a late night, I noticed that Olivia seems to be there to boost Cyrus' confidence. It is typical for black women to give out more love than they receive back. I think that Cyrus could care less about Olivia’s problems as long as he gets whatever it is he needs to get off his chest. I was upset because Cyrus pours out all of his problems and does not ask Olivia about her problems. I do not believe the love is reciprocated. Olivia seems more like a mother to Cyrus instead of a friend. I believe Cyrus decides to talk to Olivia about his problems solely to make himself feel better about his own situation. He knows that Olivia's life is not perfect, but yet he never asks her to share.

Mammy is a controlling image used to further associate black women with domestic duties, as if that is the only responsibility, they are worthy of having. Black women have always 
been the ones expected to fulfill white patriarchy ideologies and fantasies. There is a reminder that black women do not have an option; they have no choice but to listen and provide white men and others with whatever it is they need at the expense of their own personal lives. 


\section{JEZEBEL OLIVIA}

Throughout many of the episodes, Olivia partakes in sexual activity with multiple men. In Patricia Hill Collins’ (2000) book, the Jezebel is discussed as a controlling image of black women. Collins makes it clear that sexuality plays a role in all of the controlling images; however, Jezebel is the only controlling image that focuses on sexuality and sexual impurity exclusively. According to Collins (2000), “efforts to control Black women’s sexuality lie at the heart of Black women’s oppression” (p. 81). Because sexuality is used to divide the pure and impure, the good from the bad, that would explain why there needed to be a controlling image dedicated specifically towards black women’s sexuality.

The revealing of Olivia and Fitz’s first sexual act occurs in episode six of season one. Scandal goes back in time to show viewers how Olivia and Fitz first become intimate. Olivia began as Fitz’s campaign manager. After a long day of traveling for Fitz’s campaign, Olivia and Fitz walk to the hotel room, seconds later, Olivia removes her clothing and they proceed to have sex. I do believe in expressing your agency and being free to do as you please. However, my issue is that Scandal does not try to hide Olivia’s sexuality even a little bit. Instead, she is blatantly depicted as a promiscuous Jezebel, which I believe is a horrible misrepresentation of black women. Concerning my upbringing, my family did not flaunt their sex lives; sex just was not the topic on a Sunday evening at the dinner table. That is probably the reason I feel the way I do about Olivia mimicking the racial stereotypical Jezebel throughout the series.

In Episode 22 of season two, Olivia and Fitz are in a room by themselves. First, they discuss political issues and problems concerning the White House. After just a few minutes into 
the conversation, Fitz makes a move on Olivia. Olivia starts walking towards the door but something in her allows her to walk back towards Fitz. Undeniably, Olivia cannot resist. Fitz clutches Olivia by her blazer and pulls her in for a kiss. If creator Shonda Rhimes wanted Olivia to show self-control, she could have easily made Olivia pull away from Fitz. Instead of pulling away, Olivia kisses back. It is clear Olivia wants it to happen, even despite that Fitz is a married man.

We all know the storyline of a single promiscuous black female; it never ends well. The Jezebel cannot stop at one guy, she needs multiple men. Throughout the show, Olivia has sex with at least three men. One of those men happens to be Jake Ballard (Scott Foley). Jake, too, has a close connection with the White House. He was formally the White House Chief of Staff, United States Navy Admiral, and Command of B613 - a secret organization run by the government.

In Season five, episode 11, Olivia has sex with Jake, and after sex, this conversation takes place:

Jake: "I’m glad you could get past your issues with me.”

Olivia: “This isn’t happening again.”

Jake: "Yes, it is."

Jake continues to zip his pants and then walks away from Olivia. Olivia is still lying in the bed naked under the sheets. The statement that Jake makes to Olivia must get to her because she has a puzzled look on her face and seems to be in deep thought. What makes it more unsettling is that in the season before this one, Olivia slept with another random man one night and another night she is back sleeping with Fitz. One may argue that Olivia is exercising her agency in each of the sex scenes because Olivia has sex with the men and goes on about her 
business as if nothing ever happened. It could be true that she wants to have sex with multiple men; she has a right to feel that way. However, I believe Olivia can exercise her agency and yet still reinforce the Jezebel stereotype, which I think black women and black female characters should avoid doing at all costs.

Lastly, in episode five of season three, Olivia receives a message for her to meet in President Grant's office. Olivia rushes into the office with a seductive smirk on her face. When Olivia finds out that President Grant is not in sight, and that his wife Mellie Grant is actually in the office, it turns Olivia off and her seductive smirk turns into just a smirk.

Mellie states, "I like your little boyfriend, does he have a wife?”

Olivia attempts to leave the office, but Mellie convinces her to stay. By analyzing Olivia's facial expressions, she seems to be very unapologetic that she had intentions to seduce President Grant. This is only another example of Olivia portrayed as a hot mama looking to charm a man with her sexual intentions. Although, she is unable to go through with her plan to bewitch him, her motives are anything but good. 


\section{SAPPHIRE OLIVIA}

Sapphire is a negative stereotype of the Black woman to which I can personally relate. There have been many times I was forced to change my tone because I was told I sounded like I had an attitude. There has always been a mission to monitor and control black women’s attitudes and I understand that fully. Patricia Hill Collins (2000), discusses the Black Matriarch image, which is ultimately the same or very similar to the Sapphire. I believe that The Sapphire is one of the most misunderstood negative tropes of the black woman, however, that is not an excuse to conform to this stereotype. Black women and black female characters should not take on Sapphire-like behaviors simply because society will associate them as aggressive no matter what. I believe we should still attempt to change the narrative so that we are not living up to the stereotype. I find myself upset with Olivia because she is unrepentantly rude and aggressive.

Olivia is depicted as a Sapphire in episode 15 of season five. Olivia finds herself in a heated discussion with a few people. Olivia seems frustrated because she is trying to do her job, but they are against her. Olivia raises her voice and points her finger to make a point. Olivia thinks she is doing her job and speaking with passion, but the others do not seem to think so. Instead, one guy proceeds to say that Olivia is a sore loser. As Olivia walks away, one female says, “save it Richard, she’s just posturing.” Olivia is seen as just another black woman with an

attitude. The group felt that Olivia was trying to be overly aggressive in order to scare them. Regardless, if Olivia has a reason to be angry, I will argue that she could have still apologized for the way that she came off, but clearly, she does not wish to change their opinions about her being rude and aggressive. 
Olivia can be flat out dogmatic. Throughout each of the seasons, Olivia has her moments where she appears to be short-tempered. Episode 16 of season six, Olivia is angry and rushes into the home of her father Rowan "Eli” Pope (Joe Morton). Olivia says to Rowan, "I wanted to share this world with you, I want a father, but cross me again and I'll kill you” (Rhimes, 2012). Olivia does not have the best relationship with her father. In the beginning of the series, he was Command of B613 before Jake Ballard took over. Olivia did not like that her father was a "bad" guy. He is responsible for the killing and assassination of many people on the show. Because Olivia looks at herself as a savior of everyone, she cannot bear with the fact that she has a father that kills for a living. This probably explains why Olivia is very shady towards her father.

In season three of episode five, her father, Eli, invites Olivia to dinner. They have a contract stating that they will go out and eat dinner throughout the year. I believe they have the contract because Olivia is very stubborn, especially when it comes to her father. If they did not have the contract, she probably would have nothing to do with her father. As Olivia and Eli are sitting down at the restaurant, Olivia starts to get very aggressive. She shows lack of respect for him. When Eli asks her a question, she responds by saying, "instead of speaking my mind and being the outspoken girl, my mom taught me to be, I'm chewing my food.” Olivia acts in a very hostile way. As I watched this episode, I kept thinking Olivia is going to get up from the table and leave the restaurant because she seems really aggravated. Her eye contact, body language, and tone reveal that her father angered her. Her anger is used to justify why she responded the way she did. I will say, Olivia does have a reason to be angry because her father is not the best father, he is in and out of her life and is overall a "bad" guy. However, I disagree how Olivia is portrayed as a Sapphire, especially because the series never discusses the true problem Olivia has with her father it is just speculations that Olivia is upset with her father because of his job, as a 
professional killer. Being that viewers only have speculations about their father-daughter relationship, it is easy for viewers to make their own assumptions that Olivia is just an angry and disrespectful black female character.

The final example of Sapphire behavior I noted occurred in episode 16 of season six. In this episode Olivia and Grant have an emotional conversation about Grant's desire to become Command of B613. Olivia states this desire so called ruined her life. She has no problem voicing her concerns about Grant making this move to run the organization. In this moment, Olivia appears angry and like an emotional black female because she voices her disapproval. Clearly, Olivia is simply displeased with Grant's idea. However, her disappointment is mistaken with frustration and the belief that Olivia is trying to be bossy and tell Grant what he should do. Grant even states, “Is there ever gonna be a time you won’t tell me what to do?” This scene sends off a message that black women should fear speaking up on certain situations because if they do, then people will say they are angry or controlling. Eventually Olivia walks away from the conversation instead of explaining her reasoning for frustration.

Olivia's decision to walk away from the conversation with Grant was the right thing to do; in order to avoid a bigger confrontation. However, I think she could have handled the situation a tad better. She could have explained herself more to Grant, then maybe he would not continue to believe Olivia is being assertive. I know Olivia is not trying to come off disrespectful and overly aggressive, but it is portrayed that way. Because of the historical Sapphire image that already exists, black women may still be called angry even when they are not angry. However, black women should try their best not to take on those angry characteristics.

Personally, I remember when I was in middle school and my black, female dance coach had a long talk with our team. I remember her saying, “I am not angry; I am just passionate.” At 
the time I did not understand why she felt the need to defend her attitude, but now I understand. She did not want to be mistaken as angry because maybe we would not have received what she was trying to tell us. Black women have to defend certain words or actions because it could be mistaken as anger. Patricia Hill Collins’ (2000) book discusses the Black Matriarch’s controlling nature (which is similar to Sapphire) because it is essential that we understand how presenting black women as angry beings can further oppress them.

According to Melissa Harris-Perry, author of Sister Citizen: Shame, Stereotypes, and Black Women in America (2011), “sisters can sometimes get their way by confirming the expectation that they are threatening and angry, but doing so may leave them feeling that they have not been heard at all” (p. 92). It is very unfortunate that the Sapphire image has been created, and as difficult as it might be not to come off as aggressive, because one might feel that their point is not being heard, as a black woman I believe black women should try their best not to resemble the Sapphire. 


\section{DISCUSSION}

A content analysis of the show revealed three themes that helped better identify Olivia Pope. The first theme, The Mammy, displays Olivia as the caregiver. The second theme, The Jezebel, displays Olivia as hypersexual. Lastly, the third theme, The Sapphire, displays Olivia as the angry black woman. Collins (2000) discusses each of these stereotypes as controlling images used to keep black women oppressed. She also talks about black women's reactions to the controlling images, stating that some resist these images and replace them with other controlling images. It is my belief that if there are black women that choose to resist these controlling images than we know these images must convey some form of negativity. Although, I believe that Olivia is a horrible representation of black womanhood, I have to be honest and ask myself if she was not depicted as a Mammy, Jezebel, or Sapphire then what other way could she have been depicted as? Because black women have always been oppressed groups it is difficult to believe that there is a "right" way to completely portray black women. I think it is extremely difficult not to replace controlling images with other controlling images.

The creator and producer of Scandal, Shonda Rhimes, is a black woman. She is very popular with television audiences. She has a number of television shows where black women play the main characters. Rhimes is definitely a notable black woman. She creates heroic black female characters, which is not normal to see on television. I think that this is what makes her shows so successful. In an interview where she specifically talks about her feelings about Scandal, she states, “we’ve created a world in which we stopped seeing these characters on televisions and it's a magical anomaly that they're there, getting to be a three-dimensional 
character on television isn't something that only happens to white people” (Ramos, 2018). I believe her intentions for Olivia to be a different type of black female character were pure. But as I stated before, it is challenging not to replace controlling images with other controlling images. I think that her plan was for Olivia to be portrayed as something different than the traditional black female characters, but all in all, she was unable to escape those portrayals. There are scenes that I have mentioned in my findings where I believe that Rhimes had the opportunity to change the narrative of Olivia being viewed as the typical black female character. For example, if Rhimes wanted Olivia to show self-control, and not be presented as a Jezebel, then she could have easily made Olivia have a stable love life. Olivia did not have to be married but should have had a healthy relationship with only one man. Instead, Olivia has multiple sex partners and is in love with a married man, which Rhimes does not address. It makes me angry; I want to know more. Does Rhimes think it is "positive" or "good" to embrace singleness and "whorishness" within the black female community? I am not sure what Rhimes thinks, but I believe a more positive representation of black women would be to present them in a more honorable way. Does this make me too radical or too conservative? I simply just want to see black female characters presented much better than they are being presented. I want to see more uplifting black female characters.

Another thing worthy to discuss is how Rhimes’ production staff felt about the character of Olivia Pope. It appears that majority, if not all of Rhimes' production staff, agrees with how Olivia is being depicted. Personally, I believe if the majority were against Olivia's character then Scandal would not exist. It is extremely difficult to find interviews where Rhimes' production staff is stating anything negative about the show or Olivia Pope. However, I did watch an interview on YouTube where Kerry Washington and others from the cast, including Rhimes, 
were present to conduct an interview for Paleyfest LA in 2016. During the interview a black woman from the crowd asked Kerry Washington if she could write her own ending to the show, what she would do. Washington answered by stating:

At no point in these five years has any decision that Olivia's made been because of something I wanted, um, it has been because of who Olivia is in the brains of these writers. So, to be honest with you, I don’t really feel like I have that control over her, like she is very real to me, which can make me sound crazy, but, she is very real to me, and I feel almost like my job is to witness her and hold a space for her, a very nonjudgmental space for her and allow her to be who she is” (Bill, 2017).

This is a very bold statement; she basically lets us know that she stands by Shonda Rhimes' decision in creating Olivia just the way she is. I will admit I am disappointed in Kerry Washington's response. Her statement shows how people can really view the world differently. Because I take a more conservative stand, which has everything to do with how I was raised, I tend to think more traditionally. I do not agree with letting people do whatever it is they want to do. Going back to the story about my grandmother, she put restrictions in place to protect our eyes and ears from negativity on television. I do not believe she was being judgmental; I believe she was being a protector. Again, I understand the concept of expressing your agency. However, I believe my agency does not take precedence over my morals. There are standards I have for myself as a black woman; I do want to be viewed as a footstool-servant, hoochie mama, or aggressive shrew. The same standards I have for myself are the same standards I have for black female characters.

Next, the stereotypes or controlling images are not as obvious these days on television. These controlling images could not be blatantly put back on television because there would be a 
lot of upset viewers. Instead, we get black female characters like, Olivia Pope. Olivia is not the typical black female character. She is a remix, portraying multiple stereotypes all in one, which makes it more difficult to fully understand her character. If Olivia was only portrayed as one of the stereotypes it would be too obvious, and black women would be upset and offended. Therefore, I believe Scandal would not have been a hit series and majority of their viewers would not be African American.

Overall, my position is that black women should be portrayed on television in a positive manner. They should be presented in an honorable or heroic way. I do not think that black female characters should be presented as unstable, sexually immoral, and aggressive servants. I see myself as a hard-working and respectful woman. If my life was being portrayed on television, I would want people to see me as pure and stable. My biggest problem with Scandal and many television shows like it, is that it seems to glorify and magnify these traditional controlling images. Although, these controlling images are extremely difficult to escape, it is my opinion that we can eliminate or lessen this problem by presenting black female characters as pure as possible. Perhaps, we need to see more of the Black Lady controlling image Patricia Hill Collins discusses in her book. The Black Lady image can seem to be positive because she is a hard-working middle-class black woman, however it is still a controlling image. Maybe the solution is creating more black female characters that have a range of images. Maybe we need more black female characters in both their profession and in a happy and healthy relationship with their partner. Is this too much to ask for? Why would we want to embrace the negativity that may come with black womanhood? I am tired of seeing black female characters being depicted as being "messy." Bottom line: we still have ways to go. We have not arrived at the 
finish line; there are still female characters being depicted negatively on television. In the paragraph below, I will discuss next steps for the future. 


\section{LIMITATIONS AND SUGGESTIONS FOR FUTURE RESEARCH}

First, I believe there are limitations to my sampling approach. Selecting a random sampling approach for my study means that I chose only a few selected episodes out of the 126 episodes. This means that I did not watch every episode, which limits some of the examples I am able to use; this could cloud one's overall judgement of the show. In order to receive a fuller and clearer understanding of the show, it is best to analyze all episodes.

Next, I believe that one should investigate Olivia's’ identity. Olivia refers to herself as a gladiator. The word gladiator originated from the Romans. The Roman gladiators were enslaved entertainers designed to fight one another. According to Reid (2006), "the Roman idea of a gladiator is one who is "crude, loathsome, doomed, lost . . . utterly debased by fortune, a slave, a man altogether without worth and dignity, almost without humanity” (p. 39). I believe there is some significance in Olivia Pope referring to herself as “a gladiator in a suit.” A gladiator has some of the same characteristics as a Mammy and Sapphire. A gladiator is strong, dogmatic, and a trained servant ready to fight on the behalf of others. Olivia says she is a gladiator throughout the series; however, I did not select those episodes. In the future, researchers should examine and analyze the scenes where Olivia talks about being a gladiator and use as evidence to further prove her Mammy-like and Sapphire-like characteristics.

Also, I believe that an investigation of the biblical Jezebel will open new doors to explore my research question, how the television show Scandal reconfirms African American female stereotypes. The Biblical Jezebel and the raced Jezebel are very similar, but yet, not enough research comparing the two has been produced. In the future, I suggest that the Biblical Jezebel 
is unraveled and investigated much more. According to Wells (2018), "Jezebel is known in the Bible as the main source for turning God's people towards idol gods” (p. 1). Jezebel in the Bible was well known for distracting people from God. The raced Jezebel is portrayed as a distraction from white patriarchy. However, there is little to no work relating the two types of Jezebels. More research concerning the Biblical Jezebel would only help emphasize the raced Jezebel.

Lastly, I recommend that in the future, researchers consider Olivia Pope’s physical appearance. In research, physical appearance is usually included when discussing Mammies.

West (1995) noted that “Mammy’s physical appearance was depicted as obese and a dark-complexioned woman with African features” (p. 459). If we look at history, black women have always been shamed for their bigger bodies, and bigger features such as their big buttocks. Sarah Baartmann, better known as the Hottentot Venus, was a South African woman, displayed as a freak show attraction in Europe in the 19th century. Historians suggest that Baartmann had what was called steatopygia, resulting in extremely protuberant buttocks due to a build-up of fat. These made her a cause of fascination when she was exhibited at a venue in London's Piccadilly Circus (Parkinson, 2016). It was even allowed for wealthy customers to pay and see Baartmann appear in their homes. Baartmann's body was put on display for wealthy customers to observe. To whites, fat butts and fat bodies were not normal; therefore, they viewed these physical characteristics as weird and off-putting, as "other."

hooks (1992b) discusses the history of black women’s bodies stating, "their body parts were offered as evidence to support racist notions that black people were more akin to animals than other humans” (p. 114). hooks started off with a personal story of her going out to eat with colleagues who laughed at a row of gigantic black breasts while at the restaurant. She states: 
We are living in a world where white folks are no longer nursed and nurtured primarily by black female caretakers, they do not see these symbolic breasts and consciously think about mammies. They do not see this representation of chocolate breasts as a sign of displaced longing for a racist past when the bodies of black women were commodity, available to anyone white who could pay the price. (hooks, 1992b)

It is clear that hooks is hurt and offended by the laughs, so she goes on to share her displeased attitude towards the new excitement and glorification of displayed black female big body parts. When hooks sees these displayed body parts she thinks about the connection between contemporary representations and the types of images popularized from slavery, such as the Sarah Baartmann image (hooks, 1992b). There is a negative connotation that comes with black women having bigger body parts, which would make sense why Mammy is painted as a black woman with a big body. Mammy is also painted as a darker skinned black woman.

According to Lindsey (2011):

Light-skinned, black women were marketed as "Negroes fit for domestic service” within their masters' homes. Slave traders often communicated the idea that light-skinned blacks' closer proximity to whiteness in their physical appearance rendered them comparatively more attractive to slave owners in search of slaves to work in their homes than dark-skinned blacks. (p. 101)

The lighter you were, the more privileges black women received. They were still not equal to whites, but they were "better than” darker skinned Blacks. Neal \& Wilson (1989) propose that in our society female attractiveness is associated with fair skin. When I was growing up, I remember people saying “the light-skinned girl” was the most beautiful girl, of course that 
is only if she was not fat. It bothered me that the black community identifies black females as attractive or unattractive based on their skin tone.

In addition, light skinned, skinny black women are not only viewed as more attractive to society, but they also tend to receive better opportunities than a darker black female. According to Keith and Herring (1991), "fair-skinned blacks had higher levels of attainment than darker blacks on virtually every dimension of stratification” (p.761). Also, it is reported that fair skinned women receive better jobs, higher salaries, more educational opportunities, and have higher family incomes (Keith \& Herring, 1991). This made me reflect on the time that I was sitting in my grandfather's living room viewing a picture of his great grandfather who appeared very light-skinned. I learned that same day that my grandfather's great grandfather was only able to obtain a good job in Louisville because he passed for a white man. Olivia is not obese, but she is a brown skinned black woman. I would love to see future work concerning Olivia's physical appearance and how it relates to the controlling images Patricia Hill Collins (2000) discusses. 


\section{CONCLUSION}

Positive representation of black women in television matters. The caretaking Mammy, the promiscuous Jezebel, and the angry Sapphire are three historical stereotypes aimed to destroy black womanhood. These stereotypes derived directly from slavery and have kept black women oppressed. Sadly, Mammy, Jezebel, and Sapphire are present in television shows convincing viewers that these controlling images are accurate reflections of black women.

We see these negative stereotypes in the television show Scandal. It is a major problem that Olivia Pope is portrayed as a Mammy, Jezebel, and Sapphire. As a black woman, I believe black female characters should positively embrace black womanhood, especially shows such as Scandal, which is watched by predominantly African Americans. Ultimately, the show needs to represent blackness in a way that uplifts black women. However, it does not; the show is disappointing. Scandal reconfirms the existing negative stereotypes of black women. I hope my study will encourage viewers to question whether black female characters reconfirm the negative stereotypes such as Mammy, Jezebel, and Sapphire, and if so, I hope they will be able to answer why or how the black female character reconfirms those stereotypes. 


\section{REFERENCES}

Bill, K. (2017, July 15). Scandal Cast / Paleyfest LA 2016 (part 6 / the end) [Video]. YouTube. https://youtu.be/wKGIVvlwKiU

Bogle, D. (2001). Toms, coons, mulattoes, mammies, and bucks: An interpretive history of Blacks in American films. New York: Continuum.

Breines, W. (2007). Struggling to connect: White and black feminism in the movement years. Contexts, 6(1), 18-24.

Brown, D. L., White-Johnson, R. L., \& Griffin-Fennell, F. D. (2013). Breaking the chains: Examining the endorsement of modern Jezebel images and racial-ethnic esteem among African American women. Culture, health \& sexuality, 15(5), 525-539.

Burton, N. K. (2017). Representations of Black women’s mental illness in HTGAWM and being Mary Jane In S. Evans, K. Bell, N. Burton (Eds.), Black women's mental health: Balancing strength and vulnerability, (pp. 57-74). Albany: State University of New York Press.

Callen, A. (2012). Almost There, Indeed: Disney Misses the Mark on Modernizing Black Womanhood and Subverting the Princess Tradition in The Princess and the Frog [Master’s thesis, DePaul University]. https://via.library.depaul.edu/cmnt/1

Chaney, C., \& Robertson, R. (2016). Chains of psychological enslavement: Olivia Pope and the celebration of the black mistress in ABC's Scandal. Africology: The Journal of Pan African Studies, 9(3), 126-153. 
Collins, P. H. (1986). Learning from the outsider within: The sociological significance of Black feminist thought. Social problems, 33(6), s14-s32.

Collins, P. H. (2000). Black feminist thought: Knowledge, consciousness, and the politics of empowerment. Routledge.

Donovan, R. A. (2011). Tough or Tender: (Dis) Similarities in White College Students’ Perceptions of Black and White Women. Psychology of Women Quarterly, 35(3), 458468.

Garrison, S., \& Jenkins, J. O. (1986). Differing perceptions of Black assertiveness as a function of race. Journal of Multicultural Counseling and Development.

Gomez, S. L., \& McFarlane, M. D. (2017). “It’s (not) handled”: race, gender, and refraction in Scandal. Feminist Media Studies, 17(3), 362-376.

Gordon, M. K. (2008). Media contributions to African American girls' focus on beauty and appearance: Exploring the consequences of sexual objectification. Psychology of Women Quarterly, 32(3), 245-256.

Grayman, N. (2005). Sapphire: Exploring the Power of a Popular Stereotype. Psych Discourse, 39, 10-13.

Grier, W. H., \& Cobbs, P. M. (1968). Black rage. New York: Basic Books.

Harris-Perry, M. (2011). Sister Citizen: Shame, Stereotypes, and Black Women in America. New Haven: Yale University Press.

Heath, L., \& Petraitis, J. (1987). Television viewing and fear of crime: Where is the mean world?. Basic and Applied Social Psychology, 8(1-2), 97-123. 
Henry, B. A. (2014). I Am Not Your Mammy: Media Role Models, Size Discrimination, and “Fat” Black Women in the Workforce. Revue YOUR Review (York Online Undergraduate Research), 1, 51-65.

hooks, b. (1989). Talking back: Thinking feminist, thinking black. Boston, MA : South End Press.

hooks, b. (1992). Selling hot pussy. In L. Grossberg, C. Nelson, P. Treichler (Eds.), Black Looks: Race and Representation, London: Turnaround (pp. 61-79). South End Press.

hooks, b. (1992). The Oppositional Gaze: Black Female Spectators. In L. Grossberg, C. Nelson, P. Treichler (Eds.), Black Looks: Race and Representation, London: Turnaround (pp. 115-133). South End Press.

Jewell, K. S. W. (1976). An analysis of the visual development of a stereotype: the media's portrayal of mammy and Aunt Jemima as symbols of black womanhood [Doctoral dissertation, The Ohio State University].

Etd.ohiolink.edu/!etd.send_file?accession=osu1487003143384243\&disposition=inline

Jones, T., \& Norwood, K. J. (2016). Aggressive encounters \& white fragility: Deconstructing the trope of the angry black woman. Iowa L. Rev., 102(2017), 2017-2069.

Keith, V. M., \& Herring, C. (1991). Skin tone and stratification in the Black community. American journal of sociology, 97(3), 760-778.

Lindsey, T. B. (2011). Black no more: Skin bleaching and the emergence of new negro womanhood beauty culture. Journal of Pan African Studies, 4(4), 97-116.

Lomax, T. A. (2018). Jezebel unhinged: Losing the black female body in religion and culture. Duke University Press. 
Neal, A. M., \& Wilson, M. L. (1989). The role of skin color and features in the Black community: Implications for Black women and therapy. Clinical Psychology Review, 9(3), 323-333.

Parkinson, J. (2016, January 7). The Significance of Sarah Baartman. BBC News Magazine, 7. bbc.com/news/magazine-35240987

Pilgrim, D. (2002). The Jezebel Stereotype [Article]. Jim Crow Museum Website. http://fir.ferris.edu:8080/xmlui/bitstream/handle/2323/4778/Jezebel\%20Stereotype.pdf?se quence $=1$

Ramos, D. (2018, April 18). Shonda Rhimes Says There’s No Way To Describe The 'Scandal” Finale, Talks Legacy of Olivia Pope. Deadline, Retrieved from https://deadline.com/2018/04/shonda-rhimes-scandal-finale-abc-kerry-washington-oliviapope-1202366413/

Reid, H. L. (2006). Was the Roman gladiator an athlete?. Journal of the Philosophy of Sport, 33(1), 37-49.

Rhimes, S. (Producer). (2012). Scandal [Television Series]. Los Angeles, CA: ABC.

Thomas, A. J., Witherspoon, K. M., \& Speight, S. L. (2004). Toward the development of the stereotypic roles for Black women scale. Journal of Black Psychology, 30(3), 426-442.

Vega, T. (2013). A Show Makes Friends and History. The New York Times. Retrieved from https://www.nytimes.com/2013/01/17/arts/television/scandal-on-abc-is-breakingbarriers.html?auth=link-dismiss-google1tap

Versluys, E. (2014). Stereotypes of African American Women in US Television. Analysis of Scandal and Hawthorne [Master's thesis, Ghent University]. https://lib.ugent.be/catalog/rug01:002162804 
Wells, A. (2018, November 2-4). Unearthing Jezebel: Reconstructing the Jezebel's and the Black Women’s Narratives [Paper Presentation]. REA Annual Meeting, Washington DC. Religiouseducation.net/papers/rea2018-wells.pdf

West, C. M. (1995). Mammy, Sapphire, and Jezebel: Historical images of Black women and their implications for psychotherapy. Psychotherapy: Theory, Research, Practice, Training, 32(3), 458-466.

West, L. M., Donovan, R. A., \& Daniel, A. R. (2016). The price of strength: Black college women's perspectives on the strong Black woman stereotype. Women \& Therapy, 39(34), 390-412. 


\author{
CURRICULUM VITA \\ Chelsy Leann Golder \\ 1725 William E Summers III Avenue \\ Louisville, KY 40211
}

\title{
$\underline{\text { Education }}$
}

University of Louisville, 2018 - 2020

- Master of Arts in Communication

Northern Kentucky University, 2014-2018

- Bachelor of Arts in Electronic Media \& Broadcasting

- Minor in Communication

\section{Work Experience}

- Anthem, Executive Leadership Talent Acquisition Coordinator, 2018-now

\section{Teaching Experience}

- Introduction to Public Speaking, University of Louisville, 2019-now

\section{Leadership/ Volunteer Experience}

- Habitat for Humanity, Louisville, Kentucky, 2019

- $\quad$ Resume building workshop, 2019

\section{$\underline{\text { Skills }}$}

- Web coding

- Coding qualitative data 